\title{
Screening of rapeseed-mustard varieties against mustard aphid (Lipaphis erysimi)
}

\section{Nand Kishor Maurya ${ }^{1}$, Rajendra Singh ${ }^{1 *}$, Joginder Singh ${ }^{2}$, Rashmi Nigam ${ }^{3}$ Wajid Husan ${ }^{4}$ and Anant Kumar ${ }^{5}$}

\author{
${ }^{1}$ Department of Entomology, SVPUAT, Meerut, (U. P.), India, \\ ${ }^{2}$ Department of Horticulture, Janta Vedic College Bauraut, (U. P.), India \\ ${ }^{3}$ Department of Plant Pathology, Janta Vedic College Bauraut, Uttar Pradesh, India \\ ${ }^{4}$ Department of Entomology, KVK, Jehanabad, Bihar Agriculture University, Bihar, India \\ ${ }^{5} \mathrm{KVK}$, Ghaziabad, SVPUAT, Meerut, (U.P.), \\ *Email: neelu.nigam@gmail.com
}

\begin{abstract}
An examination was carried out to study the screening of rapeseed-mustard varieties Brassica spp. and evaluation of novel insecticides against aphid, Lipaphis erysimi (Kalt.) in randomized block design with three replications at Crop Research Centre of Sardar Vallabhbhai Patel University of Agriculture and Technology, Meerut during Rabi 2014-15. The aimed of screening to find out most tolerant variety against mustard aphid Lipaphis erysimi under field condition. The screening was done based on the parameters of aphid infestation index and aphid population count. The result revealed that differential reaction among varieties ranged from highly susceptible to highly tolerant. Among the twenty varieties tested, Pusa Jagnath and RLM-619 possessed highly tolerant and susceptible to mustard aphid.
\end{abstract}

Keywords: Screening, mustard aphid, oilseed, test insect, tolerant.

Paper cited: Maurya, N.K., Singh, R., Singh, J., Nigam, R., Husan, W. and Kumar, A. (2018). South Asian Journal of Food Technology and Environment, 4(2): 709-716.

\section{Introduction}

Brassica oilseed crops are the major Rabi oilseed crops grown in India, which is collectively referred to as rapeseed-mustard. Aurvedic Samhitas describes the use of 'Sarson' in India. In Sanskrit literature, 'sorson' seeds have been described as antiseptic (Das, 1997). Oilseed crops play an important role in agricultural economy of India. It constitutes the second largest agricultural product in the country next to food grains. India holds first position as a grower, producer, importer and exporter of vegetable oils in the world scenario. The vegetable oil scenario is very complex and is greatly influenced by market forces, conflicting interests, vagaries of weather, technology and various biotic and a biotic problem. Rapeseedmustard is self-pollinated, cruciferous plant belonging to genus Brassica, originated from eastern Afghanistan and adjoining parts of India and Pakistan. Rapeseed-mustard is the second most important oilseed crop in India and constitutes the major source of edible oil for human consumption and cake for animals. India is the largest rapeseed-mustard growing country in the world, occupying first position in area and second position in production after China. Brassica crops account for 30 per cent of the total oilseeds production and 13 per cent of the country's gross cropped area.

Mustard seed is the second largest produced oilseed in the world with an area of $37.0 \mathrm{~m} \mathrm{ha}^{-1}$, with the production of $63.09 \mathrm{~m}$ tonnes and the productivity of $18.50 \mathrm{q} / \mathrm{ha}$. In India it had the area of $6.3 \mathrm{~m} \mathrm{ha}^{-1}$ with production of $7.37 \mathrm{~m}$ tonnes and productivity of $11.90 \mathrm{q} / \mathrm{ha}$. India contributes $28.3 \%$ and $19.8 \%$ in world acreage and production. India produced around 7.4 MT of rapeseed-mustard next to China (11-12 MT). Among the entire oilseed crops producing states in India and in U.P the area of rapeseedmustard during the year 2013-14 was recorded $4.70 \mathrm{~m} \mathrm{ha} a^{-1}$ with production $2.5 \mathrm{mT}$ and productivity of $890 \mathrm{~kg} / \mathrm{ha}$ (Anon, 2014). The incidence and multiplication of insect pests of mustard crop greatly depend upon ecological factors. Thus the pests require need based application of insecticides at appropriate stage so 
as to minimize their residues in mustard oil and environment and hazards to natural enemies and biodiversity the mustard aphid, Lipaphis erysimi (Kaltenbach), is the key pest of rapeseedmustard. Nymphs and adults suck cell sap from leaves, shoots, flower buds, flowers and pods. This pest is more abundant from December to March when it infests various cruciferous oilseeds and vegetables. The cloudy and cold weather $\left(20^{\circ} \mathrm{C}\right.$ or below), with high relative humidity $(70-75 \%)$ are very favourable conditions for the multiplication of this pest. The yield losses due to this pest vary with the variety, agro technological practices and environmental factors. However, it causes the yield losses up to 54.2\% (Bakhetia and Sekhon, 1989).

The indigenous species of rapeseedmustard grown in India i.e. Brown sarson (Brassica campestris var. brown sarson), Indian mustard (Brassica juncea), gobhi sarson (Brassica napus), Kiran rai (Brassica carinata), toria (Brassica rapa var. toria), taramira (Eruca sativa) and yellow sarson (Brassica rapa var. yellow sarson). These crops are being cultivated in about 53 countries spreading over the six continents (Europe, Africa, North America, South America, Oceania and Asia) across the globe. In Asia, it is primarily cultivated in China (Amer $e t$ al., 2010). Asian continent alone contributes $59.1 \%$ of the acreage and $48.6 \%$ of the world production. It causes damage directly by sucking phloem from different parts of plant and indirectly as a vector of plant viruses. The attack is severe in those regions where the numbers of cloudy days are more during the pest activity period. On heavy infestation, aphids are largely congregated underside of leaves, they curling and yellowing them and plants fail to develop pods, if young pods develop do not produce healthy seeds and also resulting plant to loss their growth (Mamun et al., 2010). The yield loss in rapeseedmustard also varies with their germplasms and agro-ecological practices (Ansari et al., 2007). The pest survives on other Brassica host plants for some time after the rapeseed-mustard crop is harvested. The winged form of mustard aphids migrate to the hilly parts of the country and pass the unfavourable season there on Brassica crops as wingless form. As soon as the favourable conditions prevail in plains, wings appear and aphids migrate to the plain part of the country through gliding.

\section{Materials and methods}

The experiment was conducted at Chirori farm Crop Research Centre (CRC) of Sardar Vallabhbhai Patel University of Agriculture and Technology, Meerut. Two separate field experiments were conducted for recording of screen of mustard aphid and management of mustard aphid in Brassica oilseed crops.

Test varieties: The 20 selected varieties of rapeseed-mustard viz., Vardhan, Rohini, Varuna, Narendra Rai, RRN-505, Pusa Basanti, Vaibhav, NRCDR 2, Pusa Jagannath, Pusa Mahak, RCC 4,YST-151, NRCDR 601, Pitambar, Aravali, Ashirwad, BSH-1, GSC-6, T-27,RLM-619 was screened against mustard aphid in order to determine the relative susceptibility.

Test insect: The selected varieties were screened against mustard aphid Lipaphis erysimi (Kalt). The aphid insect less than $0.25 \mathrm{~cm}$ long with two short tubes know as honey tubes, projecting from upper surface of the hind end of the body. Nymphs are light green in colour. Some adults may have whitish, but most of the adult aphids are wingless.

Damage is caused by all stages, clustering on stems leaves and pods of plants. They sack the sap from the leaves and other tender parts of plant including inflorescences, they also secrete honey dew which attracts ants and favors the growth of shooty mould. Female aphids are viviparous and do not lay eggs. The insect pest mostly active during December to February when both winged and wingless form are present. mustard.

The symbols of $T_{1}$ to $T_{20}$ have been used to represent the following varieties of rapeseed-

$\begin{array}{llllll}\mathrm{T}_{1} & : & \text { Vaibhav, } & \mathrm{T}_{11} & \text { NRCDR 02 } \\ \mathrm{T}_{2} & : & \text { Ashirwad. } & \mathrm{T}_{12} & : & \mathrm{T}-27 \\ \mathrm{~T}_{3} & : & \text { RCC } 4 & \mathrm{~T}_{13} & : & \text { Vardhan } \\ \mathrm{T}_{4} & : & \text { Pitambar } & \mathrm{T}_{14} & : & \text { Rohini } \\ \mathrm{T}_{5} & : & \text { Pusa Jagannath } & \mathrm{T}_{15} & : & \text { Pusa Mahak } \\ \mathrm{T}_{6} & : & \text { NRCDR 601 } & \mathrm{T}_{16} & : & \text { BSH-1 } \\ \mathrm{T}_{7} & : & \text { Aravali } & \mathrm{T}_{17} & : & \text { Pusa Basanti } \\ \mathrm{T}_{8} & : & \text { Varuna, } & \mathrm{T}_{18} & : & \text { RRN-505 }\end{array}$




$$
\begin{array}{lll}
\mathrm{T}_{9} & : & \text { GSC-6 } \\
\mathrm{T}_{10} & : & \text { YST-151 }
\end{array}
$$

$\mathrm{T}_{19} \quad$ : Narendra Rai

$\mathrm{T}_{20} \quad$ : RLM-619

Estimation of mustard aphid population:

To record the aphid population, ten plants were randomly selected and tagged. The aphid population was recorded on these selected plants, starting with the appearance of the aphids till the harvesting of the crop. The observation for recorded on $4^{\text {th }}$ January, 2015 and other observation were recorded at weekly intervals. The observation for recording the aphid population was confined to only top $10 \mathrm{~cm}$ of the central shoot on each plant. Further, 5 Plants from each row were selected to record the average height of the plant, average number of branches per plant and pod size of each tested variety.

\section{Standard evaluation system for aphid}

$0=$ Plant free from aphid infestation

$1=$ only few aphids with very little injury

2 = Small colonies on few twigs, no curling or yellowing of leaves

3 = Aphid colonies on almost all the twigs, stunted growth, curling and yellowing of leaves.
4 = Very heavy population of aphids on inflorescence, leaves, stem and siliqua.

$5=$ Very heavy population of aphids on inflorescence, leaves, stem and siliqua.

The average aphid index was worked out by using following equation,

$$
\text { Average aphid index }=\frac{0 \mathrm{~N}+1 \mathrm{~N}+2 \mathrm{~N}+3 \mathrm{~N}+4 \mathrm{~N}+5 \mathrm{~N}}{\text { Total number of plants observed }}
$$

Where, $0,1,2,3,4,5$ were the aphid index $\mathrm{N}=$ Number of plants showing respective aphid index.

\begin{tabular}{|c|c|}
\hline ligh & 0.1 \\
\hline Tole & $1.1-2$ \\
\hline erant & $1-$. \\
\hline ADe & $3.1-2$ \\
\hline ighly susceptibl & 4.1 \\
\hline
\end{tabular}

\section{The scales comprised (based on 0-5 grades)} are

Tables 1: Result based on aphid population count

\begin{tabular}{|l|l|l|}
\hline Aphid population & Scale & Aphid reaction \\
\hline $1-20$ mean no. of aphid/10 cm. inflorescence. & $0.1-1$ & High tolerant \\
\hline $21-50$ mean no. of aphid/10 cm. inflorescence. & $1.1-2$ & Tolerant \\
\hline $51-100$ mean no. of aphid $/ 10 \mathrm{~cm}$. inflorescence. & $2.1-3$ & Moderately tolerant \\
\hline $100-150$ mean no. of aphid/10 cm. inflorescence. & $3.1-4$ & Susceptible \\
\hline$>150$ mean no. of aphid/10 cm. inflorescence. & $4.1-5$ & Highly susceptible \\
\hline
\end{tabular}

\section{Result and Discussion}

The data on average number of aphid population among different varieties range from 9.13 to 100.84 aphids per plants are noticed during Rabi 2014-15 in Table 2. The maximum and minimum aphid populations were recorded from the variety RLM 619 and Pusa jagnath, respectively.

It is also evident from table 2 that the varieties pusa jagnath showed significantly superior to other varieties. The order of susceptibility of different varieties were observed in the order of RLM $619>$ Varuna > Krishan > Vaibhav > BSH-1 > Pusa Mahak > Aravali > Ashirwad > $R R N-505>$ Rohini $>$ NRCDR $2>$ RCC $4>$ YST$151>$ Narendra Rai >Pitambar > GSC-6 > T-27 $>$ NRCDR 601 > Vardhan > Pusa Jagnath with
$100.84,52.83,52.61,41.19,37.99,36.39,35.57$, $33.26,27.91,27.43,26.19,26.19,25.58,17.43$, $16.62,15.63,15.28,13.86,10.83$ and 9.13 aphids per plant respectively.

Further, it is also evident from the table 2 that there was no significant increase in aphid population till third observational period i.e. $3^{\text {rd }}$ standard week, there after population increases significantly on fourth observational date i.e. $5^{\text {th }}$ standard Week. The Increasing trend of aphid population was observed highly significant till $7^{\text {th }}$ standard Week ( $6^{\text {th }}$ period of observation). On seventh and onward observational periods, the aphid population decreases significantly. Thus the aphid population was increased from the fourth to sixth period i.e. $5^{\text {th }}$ standard week to $7^{\text {th }}$ standard week. The maximum number of aphid population was recorded on sixth observational 
period i.e. $7^{\text {th }}$ standard week, in all the tested varieties.

In the variety vaibhav no significant increase in aphid population up to the fourth observational period i.e. $5^{\text {th }}$ standard week was noticed. From fifth $\left(6^{\text {th }}\right.$ standard week $)$ period to sixth observational period ( $7^{\text {th }}$ standard week) there was significantly increase in aphid population, but there was sudden decrease in aphid population on the seventh and eighth observational period ( $8^{\text {th }}$ standard week to $9^{\text {th }}$ standard week). In the varieties GSC-6, YST-151, Pusa jagnath, Ashirwad, NRCDR-2, BSH-1, RRN-505Narendra rai, T-27, Rohini, Aravali no significantly increase in aphid population was observed till the third observational period. From fourth and sixth observational period, there was highly significant increase in aphid population, but highly significant decreasing trend in aphid population was observed on seventh and eighth observational period. In the varieties Pusa Mahek there was no significant increase in aphid population up to the third observational period, but significant increase in aphid population was found on the fourth and $5^{\text {th }}$ observational period ( $6^{\text {th }}$ standard week). The aphid population was started decreasing on $6^{\text {th }}$ observational period $\left(7^{\text {th }}\right.$ standard week). In the varieties Varuna, the increase in aphid population was not significant up to third observational period but from the fourth to sixth observational periods $\left(7^{\text {th }}\right.$ standard week), very highly significant increasing trend in aphid population was observed. Again on seventh and eighth observational periods, there was highly significantly cant drop in aphid population. In the varieties Krishna and RLM619 no significant increase is aphid population was recorded up to second observational period, from third observational period to sixth observational period, highly significant increase in aphid population was observed in these varieties.

Screen on the basis of susceptibility rating scale because they are some cultivar are high tolerant, tolerant, moderately tolerance susceptible, highly susceptible are divided. Firstly high tolerant average number of aphid 1-20 per plant, out of 20 varieties 7 are high tolerant, second tolerant average number of aphid 21-50 per plant, out of 20 varieties 10 are tolerant, third moderate tolerant average number of aphid 51100 per plant, out of 20 varieties 2 are high tolerant, fourth susceptible average number of aphid 100-150 per plant, out of 20 varieties 1 are susceptible and there are any varieties out of 20 they are not highly susceptible in our experiment (Table-3).
Under present investigation the average height of plant, number of branches, pod size and yield of different varieties were also recorded and presented in (Table-4) the level of infestation in relation to these factors are discussed in given section.

The variations in the above respects may be expected because the varieties differ significantly in their physical and chemical makeup including the roughness, hairy out growth, height of plants, colours, rate of growth and biochemical constitution at different levels.

Under present investigation the level of infestation was found in the order of RLM $619>$ Varuna > Krishan > Vaibhav > BSH-1 > Pusa Mahak > Aravali > Ashirwad > RRN-505 > Rohini > NRCDR $2>$ RCC $4>$ YST-151> Narendra Rai > Pitambar > GSC-6 > T-27 > NRCDR 601 > Vardhan > Pusa Jagnath.

Different Brassica spp. was grown to see their influences in incidence of insect-pests during Rabi, 2014-15. The aphid population of rapeseed-mustard was minimum (9.13 average number of aphids $10 \mathrm{~cm}^{-1}$ central twig plant $\mathrm{t}^{-1}$ ) on Pusa Jagnath, which differed significantly from maximum population of aphid (100.84 average number of $\mathrm{cm}^{-1} 10$ central twig) recorded on RLM 619.

The aphid infestations start from first week of January in all the tested varieties. Initially ( $1^{\text {st }}$ week of January) the aphid population was low but reached to peak in second week of February. Similar reported were also made by Chander et al. (2013).

Maximum incidence of aphid was found on the variety RLM 619 and minimum on the variety Pusa jagnath. The variation in aphid population may be due to a combination of antibiosis, tolerance capacity of the rapeseedmustard plant and feeding preference of the aphid. Maximum aphid population under present investigation was recorded during the flowering stage of the crop i.e. from 18 January to $8^{\text {th }}$ February. The present finding is also the conformity with the findings of Rohilla, et al., (1990), and Singh, et al. (2012).

In the present investigation the peak population of aphid was recorded on $9^{\text {th }}$ February 2015, when the average temperature and relative humidity were $16.84^{\circ} \mathrm{C}$ and 69.06 percent, respectively. The peak population of the aphid during this period was because of conductive 
Table-2: Metrological parameters during experimental period of Rabi, 2014-15.

\begin{tabular}{|c|c|c|c|c|c|c|c|c|c|}
\hline \multirow{2}{*}{ S. No. } & \multicolumn{9}{|c|}{ Observation period } \\
\hline & S.W. & Date & \multicolumn{3}{|c|}{ Temperature $\left({ }^{\circ} \mathrm{C}\right)$} & \multicolumn{3}{|c|}{ Relative humidity, \% } & $\begin{array}{c}\text { Rainfall, } \\
\text { mm }\end{array}$ \\
\hline 1. & 44 & Nov,6-12 & 29.35 & 13.85 & 21.6 & 87.42 & 38.14 & 62.78 & 0.0 \\
\hline 3. & 46 & Nov,20-26 & 25.92 & 8.85 & 17.38 & 86.42 & 36.00 & 61.21 & 0.0 \\
\hline 4. & 47 & Nov,27.Dec,03 & 28.21 & 10.57 & 19.39 & 85.57 & 30.57 & 58.07 & 0.0 \\
\hline 5. & 48 & Dec,04-10 & 26.07 & 7.42 & 16.74 & 86.28 & 27.57 & 56.92 & 0.0 \\
\hline 8. & 51 & Dec, $25-31$ & 18.5 & 5.78 & 12.14 & 86.00 & 58.00 & 72.00 & 0.0 \\
\hline 9. & 52 & Jan,1-7 & 16.42 & 9.88 & 13.15 & 94.14 & 76.57 & 85.35 & 2.2 \\
\hline 10. & 1 & Jan, $8-14$ & 15.00 & 7.21 & 11.10 & 84.00 & 82.42 & 83.21 & 1.0 \\
\hline 11. & 2 & Jan,15-21 & 16.9 & 7.64 & 12.27 & 90.71 & 74.42 & 82.56 & 0.0 \\
\hline 12. & 3 & Jan,22-28 & 16.68 & 9.44 & 13.06 & 98.28 & 73.28 & 85.78 & 1.5 \\
\hline 13. & 4 & Jan,29.Feb,4 & 19.85 & 7.88 & 13.86 & 90.28 & 54.28 & 72.28 & 0.0 \\
\hline 17. & 8 & Feb,26.Mar,4 & 22.07 & 12.55 & 17.31 & 97.14 & 65.00 & 81.07 & 11.72 \\
\hline 18. & 9 & Mar,5-11 & 24.54 & 10.21 & 17.37 & 80.83 & 41.85 & 61.34 & 2.91 \\
\hline 19. & 10 & Mar,12-18 & 26.42 & 13.78 & 20.10 & 85.28 & 56.00 & 70.64 & 0.0 \\
\hline
\end{tabular}


Table-2: Metrological parameters during experimental period of Rabi, 2014-15.

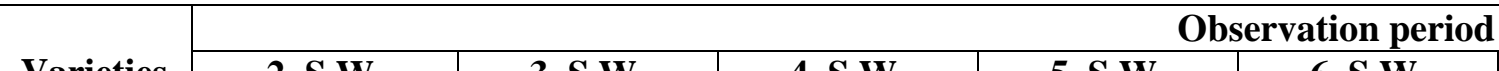

Observation period

\begin{tabular}{|c|c|c|c|c|c|c|c|c|c|}
\hline \multirow[b]{2}{*}{ Varieties } & \\
\hline & $\begin{array}{c}2 \text { S.W. } \\
(04.01 .2015)\end{array}$ & $\begin{array}{c}3 \text { S.W. } \\
(11.01 .2015)\end{array}$ & $\begin{array}{c}4 \text { S.W. } \\
(18.01 .2015)\end{array}$ & $\begin{array}{c}5 \text { S.W. } \\
(25.01 .2015)\end{array}$ & $\begin{array}{c}6 \text { S.W. } \\
(01.02 .2015)\end{array}$ & $\begin{array}{c}7 \text { S.W. } \\
(08.02 .2015)\end{array}$ & $\begin{array}{c}\text { 8 S.W. } \\
(15.02 .2015)\end{array}$ & $\begin{array}{c}\text { 9 S.W. } \\
(23.02 .2015)\end{array}$ & Mean \\
\hline GSC-6 & 1.33 & 2.60 & 5.70 & 12.56 & 24.06 & 39.36 & 34.70 & 4.73 & 15.63 \\
\hline YST-151 & 1.4 & 2.86 & 5.16 & 13.03 & 38.56 & 98.43 & 37.06 & 8.20 & 25.58 \\
\hline Vaibhav & 0.86 & 1.83 & 3.56 & 8.53 & 68.10 & 169.86 & 73.43 & 3.40 & 41.19 \\
\hline RCC 4 & 1.60 & 4.43 & 7.90 & 19.06 & 60.56 & 80.73 & 32.96 & 2.33 & 26.19 \\
\hline Pitambar & 1.50 & 3.40 & 5.00 & 11.93 & 19.90 & 66.06 & 19.23 & 5.96 & 16.62 \\
\hline $\begin{array}{l}\text { NRCDR } \\
601\end{array}$ & 1.36 & 3.03 & 5.03 & 9.36 & 28.23 & 46.46 & 16.30 & 1.13 & 13.86 \\
\hline Vardhan & 1.86 & 2.76 & 7.23 & 16.16 & 9.76 & 30.80 & 14.23 & 3.86 & 10.83 \\
\hline RLM 619 & 9.36 & 33.6 & 60.96 & 110.90 & 190.23 & 274.5 & 103.43 & 23.76 & 100.84 \\
\hline Ashirwad & 2.23 & 5.56 & 8.04 & 22.46 & 64.86 & 143.56 & 16.96 & 2.46 & 33.26 \\
\hline $\begin{array}{l}\text { NRCDR } \\
2\end{array}$ & 2.73 & 4.13 & 7.23 & 17.23 & 41.63 & 80.30 & 47.60 & 8.73 & 26.19 \\
\hline $\begin{array}{l}\text { Pusa } \\
\text { Mahak }\end{array}$ & 3.13 & 6.56 & 13.10 & 33.60 & 152.10 & 51.70 & 23.63 & 7.36 & 36.39 \\
\hline BSH-1 & 1.50 & 4.30 & 5.96 & 13.86 & 28.43 & 214.43 & 33.13 & 2.33 & 37.99 \\
\hline RRN-505 & 2.23 & 5.60 & 11.23 & 25.60 & 68.40 & 68.83 & 39.33 & 2.06 & 27.91 \\
\hline $\begin{array}{l}\text { Pusa } \\
\text { Jagnath }\end{array}$ & 1.06 & 2.00 & 3.50 & 6.53 & 6.90 & 35.13 & 16.30 & 1.63 & 9.13 \\
\hline $\begin{array}{l}\text { Narendra } \\
\text { Rai }\end{array}$ & 3.60 & 3.00 & 4.66 & 11.10 & 24.76 & 63.40 & 6.76 & 0.63 & 17.73 \\
\hline $\mathrm{T}-27$ & 1.80 & 2.66 & 5.70 & 12.20 & 25.23 & 66.43 & 7.73 & 0.56 & 15.28 \\
\hline Varuna & 3.83 & 6.73 & 13.40 & 36.30 & 120.96 & 200.30 & 26.73 & 14.40 & 52.83 \\
\hline Rohini & 2.46 & 3.40 & 6.70 & 14.10 & 73.10 & 72.40 & 29.86 & 17.46 & 27.43 \\
\hline Krishan & 3.00 & 13.56 & 30.86 & 61.53 & 158.26 & 141.46 & 10.50 & 1.76 & 52.61 \\
\hline Aravali & 6.40 & 8.06 & 17.56 & 47.26 & 84.93 & 105.30 & 10.36 & 4.73 & 35.57 \\
\hline Mean & 2.66 & 6.00 & 11.42 & 25.16 & 64.44 & 102.47 & 30.01 & 5.87 & \\
\hline
\end{tabular}

\section{C.D. at 5\% leve}

Varieties

Period 
Table 4: Observation of plant $i$. $e$.number of branches, plant, height, pod size and yield of different rapeseed-mustard varieties

\begin{tabular}{|l|c|c|c|c|}
\hline Varieties & $\begin{array}{l}\text { Number of } \\
\text { branches per } \\
\text { plant }\end{array}$ & Plant height $(\mathbf{c m})$ & Pod size (cm) & Yield(q/ha) \\
\hline GSC-6 & 9.13 & 158.16 & 5.50 & 10.53 \\
\hline YST-151 & 6.91 & 70.90 & 4.46 & 9.03 \\
\hline Vaibhav & 8.06 & 186.30 & 5.63 & 9.66 \\
\hline RCC4 & 9.90 & 185.30 & 3.93 & 8.96 \\
\hline Pitambar & 9.00 & 78.26 & 5.50 & 10.73 \\
\hline NRCDR 601 & 13.63 & 189.20 & 4.30 & 10.66 \\
\hline Vardhan & 8.83 & 175.73 & 4.83 & 9.86 \\
\hline RLM 619 & 12.23 & 190.66 & 5.06 & 7.03 \\
\hline Ashirwad & 9.00 & 179.33 & 5.03 & 9.13 \\
\hline NRCDR 2 & 11.30 & 181.66 & 4.20 & 9.53 \\
\hline Pusa Mahek & 8.10 & 160.56 & 4.06 & 8.96 \\
\hline BSH-1 & 9.50 & 180.03 & 4.36 & 9.50 \\
\hline RRN-505 & 12.10 & 160.50 & 4.03 & 9.73 \\
\hline Pusa jagnath & 7.96 & 167.83 & 4.20 & 10.56 \\
\hline Narendra Rai & 7.90 & 150.13 & 4.33 & 10.03 \\
\hline T-27 & 8.10 & 148.26 & 4.43 & 10.36 \\
\hline Varuna & 8.90 & 172.90 & 3.26 & 8.86 \\
\hline Rohini & 9.13 & 148.66 & 5.00 & 9.10 \\
\hline Krishan & 7.13 & 150.13 & 4.33 & 8.60 \\
\hline Aravali & 8.70 & 160.33 & 4.60 & 8.93 \\
\hline
\end{tabular}

C.D. at $5 \%$ Level

Number of branch /plant : : $\quad 2.38$

Plant height $\quad: \quad 5.20$

Pod size $\quad: \quad 0.28$

Yield $\quad: \quad 0.78$

temperature and relative humidity. Further, under present investigation it was observed that the aphid population decreases significantly from third week of February, 2015.

According to Rohilla, et al., (1990) cultivar Vardan was found tolerant to aphid population. Aphid population was greatest in Varuna cultivar is reported by Singh, et al. (2008) and Khedkar et al. (2011) while, Bhati, et al. (2015) reported that BSH-1 highly susceptible to Mustard aphid by YST-151 whereas, the cultivar

GSC-6 show highly tolerance to mustard aphid as compare to T-27 cultivar.

According to Takar et al. (2003) and Verma, et al. (2005) reported the varieties Rohini as moderately and T-59 (Varuna) was found least resistant significantly. In the present experiment the variety RLM 619 and YST-151 grew longer and shorter with height, variety NRCDR 601 and Krishan grew height and lowest in number of branch per plant and variety
Vaibhav and Varuna grew biggest and smallest pod size per plant respectively and variety Pitambar and RLM 619 they are height and lowest yield respectively.

\section{Conclusion}

Summary of the experiment conduct and results obtained are given here under the relative susceptibility of different rapeseedmustard varieties to Lipaphis erysimi (Kalt) was determined on the basis of aphid population recorded on different varieties at various observational periods. The aphid population was recorded from the top $10 \mathrm{~cm}$ of the central shoot only.

Under present investigation, none of the tested varieties were found resistant to the attack of mustard aphid, Lipaphis erysimi (Kalt), even through significantly difference in population was observed on different varieties.

The level of aphid infestation was found in following descending order: RLM $619>$ Varuna > Krishan > Vaibhav > BSH-1 > Pusa 
Mahak > Aravali > Ashirwad > RRN-505 > Rohini > NRCDR $2>$ RCC $4>$ YST-151> Narendra Rai >Pitambar > GSC-6 > T-27 > NRCDR $601>$ Vardhan > Pusa Jagnath.

The highest (100.84 per plant) and lowest (9.13 per plant) aphid population was recorded on the varieties RLM-619 and Pusa jagnath, respectively. The first appearance of aphid was noticed on $4^{\text {th }}$ January 2015 i.e $2^{\text {nd }}$ standard week. Further, the maximum aphid population was recorded on $8^{\text {th }}$ February 2015 i.e. $7^{\text {th }}$ standard week. In present investigation it was also observed that the maximum population of aphids recorded when the average temperature and relative humidity $15.13^{\circ} \mathrm{C}$ and 70.42 per cent, respectively.

\section{References}

1. Amer, M.; Aslam, M.; Razaq, M. and Shad, S. A. (2010). Effect of conventional and neonicotinoid insecticides against aphids on canola, Brassica napus L. Pakistant Journal of Zoology, 42: 377381.

2. Anonymous, (2014). Annual Progress Report of All India Coordinated Research Project on Rapeseed and Mustard. National Research Centre on Rapeseed Mustard, Sewar, 3213003, Bharatpur, Rajasthan. Pp. 155.

3. Ansari, M.S.; Barkat, H. and Quzi, N.S. (2007). Influence of abiotic environment on the population dynamics of mustard aphid, Lipaphis erysimi (Kalt.). Journal Biological Science, 7(6): 993-996.

4. Bakhetia, D.R.C. and Sekhon, B.S. (1989). Insect-pests and their management in rapeseed-mustard. Journal of Oilseeds Research, 6: 269-299.

5. Bhati, R.; Sharma, C. and Singh, R. (2015). Studies on occurrence of insectpests of different Brassica species. International Journal Current Science, 14: 51-58.

6. Chander, S.; Prasad, T.V.; Singh, R.; Singh, S.; Gautam, R.D. and Bhalla, S.
(2013). Evaluation of Different Brassica Species against Mustard Aphid, Lipaphis erysimi. Indian Journal of Plant Protection, 41(1): 38-44.

7. Das, P.C. (1997). Oilseed Crops of India. Kalyani Publishers, New Delhi, p. 273

8. Khedkar, A.A.; Patel, M.G. and Bharpoda, T.M (2011). Screening of different varieties/genotypes for their susceptibility against mustard aphid, Lipaphis erysimi (Kaltenbach). Current Biotica, 5(3): 359-363

9. Mamun M.S.A.; Ali, M.H.; Ferdous, M.M.; Rahman, M.A. and Hossain, M.A. (2010). Assessment of several mustard varieties resistance to mustard aphid, Lipaphis erysimi (Kalt.). Journal of Soil Naure, 4: 34-38.

10. Rohilla, H.R.; Singh, H. and Kumar, P.R. (1990). Preliminary screening of national varieties of Brassica juncea (L.) Czern and Coss., against mustard aphid, Lipaphis erysimi (Kalt). Journal of Oilseeds Research, 7(2):81-83.

11. Singh, M.P.; Madhushudan, N. and Singh, K.I. (2012). Management of mustard aphid, Lipaphis erysimi (kaltenbach) in rapeseed mustard with botanicals and varietal resistance. Indian Journal of Entomology. 74(3): 289-294

12. Singh, R.K. and Verma, R.A. (2008). Relative efficacy of certain inscticides against mustard aphid on Indian mustard. Journal of Agricultural Science, 78(9): 821-823.

13. Takar, B.L.; Deshwal, H.L. and Jat, B.L. (2003). Screening of different varieties/entries of Brassica juncea (L.) Czern and Coss to mustard aphid, Lipaphis erysimi (Kalt.) infestation. Annals of Biology; 19(2):209-212.

14. Verma, R.K. Agarwal, N. and Rajak, S.K. (2005). Screening of Brassica lines against mustard aphid, Lipaphis erysimi (Kalt.) infestation. Journal of Oilseeds Research; 22(1): 220-221

\begin{tabular}{|ll}
\hline Received & : Oct., 2018 \\
Revised & : Nov., 2018 \\
Published & : Dec., 2018
\end{tabular}

